\title{
Molecular identification of bacteria isolated from culture medium of rotifer fed on fishery waste diet
}

\author{
STENLY WULLUR ${ }^{1, \bullet}$, HATOPAN NAPITUPULU ${ }^{1}$, LETHA LOISE WANTANIA ${ }^{1}$, ELVY LIKE GINTING ${ }^{1}$, \\ VEIBE WAROUW ${ }^{1}$, SANDRA TILAAR ${ }^{2}$, TRINA EKAWATI TALLEI ${ }^{2}$, INNEKE FENNY MELKE RUMENGAN ${ }^{1}$ \\ ${ }^{1}$ Faculty of Fisheries and Marine Science, Sam Ratulangi University. Jl. Kampus, Bahu, Malalayang, Manado 95115, North Sulawesi, Indonesia. \\ Tel./fax.: +62-431-868027, `email: stenlywullur@unsrat.ac.id \\ ${ }^{2}$ Faculty of Mathematics and Science, Sam Ratulangi University. J1. Kampus Unsrat, Manado 95115, North Sulawesi, Indonesia.
}

Manuscript received: 5 April 2020. Revision accepted: 24 May 2020.

\begin{abstract}
Wullur S, Napitupulu H, Wantania LL, Ginting EL, Warouw V, Tilaar S, Tallei TE, Rumengan IFM. 2020. Molecular identification of bacteria isolated from culture medium of rotifer fed on fishery waste diet. Biodiversitas 21: 2735-2740. The aim of this study was 16S-rRNA sequences based molecular identification of bacteria isolated from culture medium of rotifer fed with fishery waste diet (FWD). We cultured rotifer Brachionus rotundiformis in sterilized seawater (salinity $25 \mathrm{ppt}$ ) using FWD, following the procedure in Patent No. P00201609066. Bacteria from the culture were collected, homogenized, diluted 10 to 1000 fold, spread on agar plates and incubated at $37^{\circ} \mathrm{C}$ for 24 to 48 hours. Representative colonies of the bacteria according to their morphologies were isolated for further characterization. Genomic DNA of the isolates were extracted, and the 16S rRNA gene of the isolates were amplified. Polymerase Chain Reaction (PCR) product of each isolate was sequenced and queried against the NCBI GenBank database. Six different isolates based on size, color, elevation, margin, and colony were observed during $24-48$ hours incubation at $37^{\circ} \mathrm{C}$. The $16 \mathrm{~S}$ rRNA genes of the six isolates were successfully amplified and produced DNA band at 1300-1500 bp, with quality value equal to or greater than 20 (QV20+) of each entire sequence around 941-1253 bases. Basic Local Alignment Search Tool (BLAST) queries in the NCBI GenBank and EzBioCloud database using the 16S-rRNA gene sequences showed that the six isolates belong to four different genera, i.e: Bacillus, Staphylococcus, Vibrio, and Alteromonas.
\end{abstract}

Keywords: Bacteria, diet, fish-waste, identification, rotifer, 16S rRNA

\section{INTRODUCTION}

The use of rotifer (Brachionus plicatilis species complex) as live-food for newly hatched fish larvae was initiated in early 1960s (Hagiwara et al. 2014; Hagiwara et al. 2017). Today, most hatcheries use the rotifers as indispensable live-food for fish larviculture (Kotani et al. 2017; Wullur 2017) due to their benefits such small body size, rapid reproductive rate, high population growth, relatively slow in motility, mass culture possibility and its nutritional value (Wullur et al. 2011; Wullur et al. 2013; Hagiwara et al. 2014; Rumengan et al. 2016; Wati and Imanto 2018; Wullur et al. 2018; Lee et al. 2019).

Procedure used today for culturing the rotifers uses microalgae i.e. Chlorella sp. Nannochloropsis oculata, etc (Hagiwara et al. 2017). In fact, production cost of microalgae is high due to the high investment costs and running expenses (Acien et al. 2017). For this reason, cheap food sources based on baker's yeast were introduced (Hagiwara et al. 2014; Hagiwara et al. 2017), but it provided less nutritional value particularly for eicosapentaenoic acid (20:5 n-3) and docosahexaenoic $(22: 6 \mathrm{n}-3)$ to support growth of fish larvae. Also, the baker's yeast often was a source of unstable culture or even culture crashes due to the rapid decline of water quality of the culture and therefore it is currently less attractive for fish farmers (Hagiwara et al. 2014; Hagiwara et al. 2017; Ogello et al. 2018; Ogello et al. 2019; Wullur et al. 2019;
Ogello et al. 2020). During the late 1980s, a Japanese Chlorella industry company (Fukuoka, Japan) has developed a microalga paste Chlorella V-12® as food for rotifer. The microalgal paste is convenient since it is readyto-use and could be stored for about 2 weeks without significant loss of its nutritional value (Hagiwara et al. 2014; Hagiwara et al. 2017). The microalgal paste is also more stable food for rotifer that enables aquaculturists to mass culture rotifer at high density but its price is high and not commonly available in hatcheries particularly in developing countries (Hagiwara et al. 2014). Recently, a cheap and ready-to-use diet for rotifer based on fisherywaste is being developed as an alternative to the microalgae-based feed (Ogello et al. 2018; Napitupulu et al. 2019; Ogello et al. 2019; Wullur et al. 2019; Ogello et al. 2020). Acceptance of rotifer on the diet was great, where population growth of rotifer fed the diet increased significantly about 2000 to 3000 ind./ml within approximately 3 to 5 days culture (Wullur et al. 2017), and its dietary value to fish larvae was comparable to rotifer fed with microalgae paste (Ogello et al. 2018; Ogello et al. 2019; Wullur et al. 2019; Ogello et al. 2020).

The fishery diet acts as a source for bacterial bloom which further used by the rotifer as their nutritional source for growth and development, but the bacterial species involved in decomposing the fishery diet is unknown until recently. To address this lack of information, a smallribosomal subunit $16 \mathrm{~S}$ rRNA gene was used to identify 
species of bacteria at molecular level in the present study. The 16S rRNA gene is commonly used to study bacterial taxonomy as it is present in almost all bacteria species, its function over time has not changed, and its length (1.500 bp) is large enough for informatics purpose (Fuks et al. 2018; Wantania et al. 2019; Wondal et al. 2019; Akihary et al. 2020). Understanding the bacterial composition in rotifer cultures is important for the aquaculture industry.

\section{MATERIALS AND METHODS}

\section{Procedures}

Bacterial isolation and culture

Bacterial isolates in this study were obtained from culture of rotifer Brachionus rotundiformis fed with fishery waste diet. The procedure for the preparation of the fishery waste diet was adapted as described in Patent No. P00201609066 registered in Indonesia. Culture of rotifer was conducted using sterilized seawater at salinity $25 \mathrm{ppt}$ and placed in a room at ambient temperature at around 25 $28^{\circ} \mathrm{C}$. Bacterial isolation was conducted by taking $1 \mathrm{~mL}$ water sample from the rotifer culture (rotifer population with the density of about 100 ind./ml) and was serially diluted (for 10 to 1000-fold) in sterile seawater and plated on $2 \%$ nutrient agar (NA). The NA plates were incubated for 24-48 hours at $37^{\circ} \mathrm{C}$ for bacterial colonies observations following Laboffe (2012). Representative distinct colonies of the bacteria according to their phenotype characters were isolated and grown in nutrient broth for 24-48 hours, harvested, and centrifuged (14.000 rpm for 5 minutes) for molecular analysis.

\section{Molecular identification}

Genomic DNA of the bacterial isolates were extracted using Qiaprep Miniprep Kit (Qiagen, Hlden, Germany) according to the manufacture's instruction. The bacterial $16 \mathrm{~S}$ rRNA gene was amplified using the universal PCR primer pairs (Integrated DNA Technologies-IDT, Singapore) $8 \mathrm{~F}$ (5'-AGAGTTTGATCCTGGCTCAG-3') and 1492 R (5'-ACCTTGTTACGACTT-3') (Fuks et al. 2018; Wantania et al. 2019; Wondal et al. 2019; Akihary et al. 2020). The amplification reaction was performed in a total volume of $25 \mu \mathrm{l}$, consisting of $5 \mu \mathrm{l}$ of $5 \mathrm{x}$ Hotfirepool, $17 \mu \mathrm{l}$ of ddH2O, $1 \mu \mathrm{l}$ of Primer $8 \mathrm{~F}, 1 \mu \mathrm{l}$ of Primer 1492R, and $1 \mu \mathrm{l}$ sample. Amplification for 35 cycles was performed in Professional Thermocycler (Biometra, Analytik Jena). The temperature profile for PCR was $95^{\circ} \mathrm{C}$ for $6 \mathrm{~min}(1 \mathrm{cycle}), 95^{\circ} \mathrm{C}$ for $30 \mathrm{sec}, 52^{\circ} \mathrm{C}$ for $30 \mathrm{sec}$, and $72^{\circ} \mathrm{C}$ for $30 \mathrm{sec}$ ( $\left.35 \mathrm{cycles}\right)$, followed by $72^{\circ} \mathrm{C}$ for $10 \mathrm{~min}$ at the end for final cycle. PCR products were electrophoresed on $1 \%$ agarose gel then visualized with ethidium bromide staining to check the success of PCR amplification. For DNA sequencing, the amplicons and the primers (forward and reverse) were sent to First-Base Co., Selangor, Malaysia. A BigDye® Terminator v.3.1 Cycles Sequencing Kit (Applied Biosystems, USA) was used to bidirectionally sequence the DNA, and read using an ABI PRISM® 377 automatic DNA sequencer. Sequences quality was assessed using Sequence Scanner version 2.0
Software (Applied Biosystem) and the sequence traces were trimmed, assembled and manually edited using Geneious Prime version 2020 (http://www.geneious.com, Kearse et al., 2012) prior to being subjected to $16 \mathrm{~S}$ rRNA sequence BLAST analysis at The National Center for Biotechnology Information (NCBI, https://www.ncbi.nlm.nih.gov/) and EzBioCloud (https://www.ezbiocloud.net/) (Yoon et al. 2017). BLAST result data were limited to identity percent values between $97-100 \%$, and query cover between $98-100 \%$.

\section{RESULTS AND DISCUSSION}

It is well known that rotifers consume bacteria as their nutritional source for growth and reproduction (Wullur et al. 2019). In nature, the bacteria are important food components in rotifer microbial web, while in culture, the bacteria proved to have beneficial effect on culture quality of rotifers (Loo et al. 2016) and reared fish larvae (Nevejan et al. 2018). On the other hand, there are reports which indicated bacteria as possible cause of culture crash on rotifer or larval mortality due to pathogenic outbreak (Hache and Plante 2011). Population densities of rotifer cultured using the FWD in the present study were around $100 \mathrm{ind} . / \mathrm{mL}$ at which the bacterial samples were collected. The capability of rotifer to grow and reproduce in FWD without any microalgae addition as the current procedure in larvicuture industry was also reported previously (Ogello et al. 2018; Ogello et al. 2019; Wullur et al. 2019; Ogello et al. 2020). We suggested that the FWD was the source of bacteria bloom inside the culture medium and further utilized by the rotifer as their nutritional source.

The size, color, elevation, margin, and type are wellknown characters in characterization of bacterial colonies (Sousa et al. 2015). By collecting samples from the culture medium of rotifer, we successfully isolated 6 different colonies of bacteria based on the characters of colony morphology. All isolates in this study showed small sized round type colonies (isolates F0032, F0033, F0034, F0035, F0036, and F0037) except isolate F0031, having largesized colony in comparison to other isolates. The colony color of isolates F0031, F0032, F0033, and F0035 were milky white, while whitish-pink for isolates F0036 and F0037. The colonies elevation was umbonate (F0031) and convex (F0032, F0035, F0036 and F0037), while the margins were erose (F0031) and smooth (F0032, F0033, F0035, F0036 and F0037).

Bacteria can be transmitted to fish or crustacean larvae when rotifers are given as food, and the bacteria could increase growth and survival of the larvae or vice versa. According to Fialkowska et al. (2019) and Onianwah et al. (2018), the main genera identified in rotifer and fish larviculture were Pseudomonas, Vibrio, Moraxella, and Flavobacterium. In the present study, based on BLAST result using database of $16 \mathrm{~S}$ rRNA at GenBank and EzBioCloud gene marker, we identified 5 different bacterial species (Bacillus cereus species complex, Vibrio rotiferanus, Bacillus jeotgali, Staphylococcus warneri, and Alteromonas fortis) belonging to 4 different genera 
(Bacillus, Vibrio, Staphylococcus, and Alteromonas) which present in the culture of rotifer fed FWD (Table 1).

Two isolates (F0031 and F0033) identified were belonged to genera of Bacillus, a genus of gram-positive, rod-shaped bacteria, that have been used for years as probiotics, which confer health benefits to host. The isolate F0031 has similar value (i.e. score, query cover, e-value and identity; $2593,99 \%, 0.0$, and $99.79 \%$, respectively) to B. wiedmannii (NR_152692.1), B. proteolyticus (NR_157735.1) and B. cereus (NR_074540.1; NR_113266.1; NR_115714.1) (Table 1). According to Miller et al. (2016; 2018) and Liu et al. (2017), B. wiedmannii, $B$. proteolyticus and $B$. cereus were members of $B$. cereus species complex, which comprises about 12 closely related species, and other 9 new members of the Bacillus species complex as proposed by Liu et al. (2017). $B$. cereus is a gram-positive, aerobic-to-facultative, spore- forming rod-shaped bacteria having wide distribution in the environment (Bottone 2010). B. cereus is a pathogenic bacterium that is harmful to humans and causes foodborne illness, but some strains of $B$. cereus have long been known as probiotic bacteria in rotifer culture (Md et al. 2015; Loka et al. 2016). In spite of that, B. cereus was also reported to have a significant role in enhancing growth performance of fish fingerlings (Chandran et al. 2014; Vargas-Albores et al. 2017; Sultani et al. 2019). Vargas-Albores et al. (2017) reported that B. cereus isolated from tiger shrimp (Penaeus monodon) and Pacific white shrimp (Litopenaeus vannamei) revealed growth and immune enhancer features for shellfish. B. cereus was reported to have the capability of enhancing various immune parameters, i.e. phenoloxidase, lysozyme, respiratory burst, and bactericidal activity in P. monodon (Chandran et al. 2014).

Table 1. Top five hits against Nucleotide BLASTed of 16S-rRNA gene of the bacterial isolates using rRNA type strains/prokaryotic16S_ribosomal RNA (bacteria and archaea) database setting in the NCBI GenBank

\begin{tabular}{|c|c|c|c|c|c|}
\hline Isolates & Species \& Accession number & Score & Query cover & E-value & Identity \\
\hline \multirow[t]{5}{*}{ F0031 } & Bacillus wiedmannii (NR_152692.1) & 2593 & $99 \%$ & 0.0 & $99.79 \%$ \\
\hline & Bacillus proteolyticus (NR_157735.1) & 2593 & $99 \%$ & 0.0 & $99.79 \%$ \\
\hline & Bacillus cereus (NR_074540.1) & 2593 & $99 \%$ & 0.0 & $99.79 \%$ \\
\hline & Bacillus cereus (NR_113266.1) & 2593 & $99 \%$ & 0.0 & $99.79 \%$ \\
\hline & Bacillus cereus (NR_115714.1) & 2593 & $99 \%$ & 0.0 & $99.79 \%$ \\
\hline \multirow[t]{5}{*}{ F0032 } & Vibrio rotiferanus (NR_118091.1) & 2597 & $100 \%$ & 0.0 & $99.65 \%$ \\
\hline & Vibrio rotiferanus (NR_042081.1) & 2597 & $100 \%$ & 0.0 & $99.65 \%$ \\
\hline & Vibrio campbellii (NR_119050.1) & 2588 & $99 \%$ & 0.0 & $99.58 \%$ \\
\hline & Vibrio campbellii (NR_113782.1) & 2577 & $100 \%$ & 0.0 & $99.30 \%$ \\
\hline & Vibrio alginolyticus (NR_118258.1) & 2562 & $100 \%$ & 0.0 & $99.23 \%$ \\
\hline \multirow[t]{5}{*}{ F0033 } & Bacillus jeotgali (NR_025060.1) & 2567 & $99 \%$ & 0.0 & $99.30 \%$ \\
\hline & Bacillus boroniphilus (NR_041275.1) & 2564 & $99 \%$ & 0.0 & $99.23 \%$ \\
\hline & Bacillus thioparans (NR_043762.1) & 2562 & $99 \%$ & 0.0 & $99.23 \%$ \\
\hline & Bacillus subterraneus (NR_104749.1) & 2551 & $99 \%$ & 0.0 & $99.09 \%$ \\
\hline & Bacillus selenatarsenatis (NR_041465.1) & 2536 & $99 \%$ & 0.0 & $99.22 \%$ \\
\hline \multirow[t]{5}{*}{ F0035 } & Stphylococcus warneri (NR_025922.1) & 2603 & $100 \%$ & 0.0 & $99.65 \%$ \\
\hline & Stphylococcus pasteuri (NR_024669.1) & 2579 & $100 \%$ & 0.0 & $99.37 \%$ \\
\hline & Stphylococcus pasteuri (NR_114435.1) & 2562 & $99 \%$ & 0.0 & $99.29 \%$ \\
\hline & Stphylococcus epidermis (NR_036904.1) & 2516 & $100 \%$ & 0.0 & $98.59 \%$ \\
\hline & Staphylococcus epidermis (NR_113957.1) & 2512 & $100 \%$ & 0.0 & $98.52 \%$ \\
\hline \multirow[t]{7}{*}{ F0036 } & Alteromonas fortis (MK007076) (EzBioCloud) & - & - & - & $99.56 \%$ \\
\hline & Alteromonas litorea (AY428573) (EzBioCloud) & - & - & - & $99.34 \%$ \\
\hline & Alteromonas tagae (NR_043977.2) & 2407 & $100 \%$ & 0.0 & $97.88 \%$ \\
\hline & Alteromonas litorea (NR_025780.1) & 2403 & $100 \%$ & 0.0 & $97.88 \%$ \\
\hline & Alteromonas confuentis (NR_137375.1) & 2396 & $100 \%$ & 0.0 & $97.71 \%$ \\
\hline & Alteromonas mediterranea (NR_148755.1) & 2390 & $100 \%$ & 0.0 & $97.64 \%$ \\
\hline & Alteromonas mediterranea (NR_148754.1) & 2388 & $100 \%$ & 0.0 & $97.64 \%$ \\
\hline \multirow[t]{7}{*}{ F0037 } & Alteromonas fortis (MK007076) (EzBioCloud) & - & - & - & $99.40 \%$ \\
\hline & Alteromonas macleodii (CP003841) (EzBioCloud) & - & - & - & $99.16 \%$ \\
\hline & Alteromonas macleodii (NR_114053.1) & 2435 & $97 \%$ & 0.0 & $98.68 \%$ \\
\hline & Alteromonas macleodii (NR_037127.1) & 2429 & $97 \%$ & 0.0 & $98.76 \%$ \\
\hline & Alteromonas mediterania (NR_148755.1) & 2422 & $100 \%$ & 0.0 & $97.87 \%$ \\
\hline & Alteromonas litorea (NR_025780.1) & 2407 & $100 \%$ & 0.0 & $97.65 \%$ \\
\hline & Alteromonas mediterania (NR_148753.1) & 2405 & $100 \%$ & 0.0 & $97.65 \%$ \\
\hline
\end{tabular}


Findings by He et al. (2017) suggested that the use of $B$. cereus in combination with Clostridium butyricum and Lactobacillus acidophilus can be superior to the growth and production of digestive enzymes of hybrid grouper (Epinephelus lanceolatus and E. fuscoguttatus). On the same hand, Divya et al. (2015) found that B. cereus, in combination with $B$. subtilis, $B$. licheniformis and $B$. coagulans are suitable for bioremediation of organic detritus although they did not seem to be naturally present in sufficient population densities in either the water column or sediment. Extracellular products of $B$. cereus together with $B$. subtilis strongly inhibited the growth of pathogenic bacteria Aeromonas hydrophila and Vibrio alginolyticus isolated from diseased fish (Murillo and Villamil 2011). Isolate F0033 showed highest similarity with Bacillus jeotgali (NR_025060.1), B. boroniphilus (NR_041275.1), B. thioparans (NR_043762.1), B. subterraneus (NR_104749.1) and B. selenatarsenatis (NR_041465.1) (Table 1). B. jeotgali is a probiotic bacterium, firstly isolated from a Korean traditional fermented seafood (Jeotgal) made from salted marine organisms such as fish, molluscs and crustaceans (Yao et al. 2019). There were no prior reports so far on the presence of this probiotic bacterium in rotifer culture, but the bacterium was reported to have beneficial effect on survival and development of Litopenaeus vannamei larvae (Xue et al. 2016).

The isolate F0032 showed highest similarity to Vibrio rotiferianus (NR_118091.1; NR_042081.1; NR_119050.1), $V$. campbellii (NR_113782.1; NR_118258.1) and $V$. alginolyticus (NR_118258.1). Ke et al. (2017) grouped the three bacterial species in the harveyi clade of the genus Vibrio together with $V$. harveyi, $V$. parahaemolyticus, $V$. mytili, $V$. natriegens and $V$. azureus. According to Chowdhury et al. (2011), the $V$. rotiferianus had $\leq 70 \%$ DNA hybridization similarity to its most closely related species, $V$. campbellii and $V$. harveyi, although, they shared $99 \%$ identity in 16S rRNA gene sequences. The $V$. rotiferianus is a gram-negative bacterium, was firstly assigned as a new species in 2003 and was named after its isolation source, i.e. from rotifer cultures (Ke et al. 2017). Although $V$. rotiferianus was found in rotifer culture, however, there were no reports on its pathogenicity to fish larvae through transmission from rotifer. The Vibrio genus is often reported as inhabitants at low density of marine fish larvae culture even though there were no symptoms of vibriosis appearing (Hannan et al. 2019; Istiqomah et al. 2020). On the other hand, Sahandi et al. (2019) reported the significant use of yeast or probiotics bacteria in reducing growth of Vibrio.

Isolate F0035 showed highest similarity to Staphylococcus warneri (NR_025922.1), S. pasteuri (NR_024669.1; NR_114435.1), S. epidermis (NR_036904.1; NR_113957.1). These three species are member of the bacterial genus Staphylococcus, the grampositive bacteria commonly found as part of the skin flora on humans and animals. S. warneri was reported as a resident in skin of rainbow trout and was not pathogenic or has a very low pathogenicity to the marine fish even when injected at very high concentrations (Musharrafieh et al.
2014). So far, there is no report on the presence of $S$. warneri in the culture of rotifer and its transmission from rotifer to fish larvae.

Isolate F0036 and F0037 showed lower similarity to several species of Alteromonas retrieved from GenBank. However, using EzBioCloud, F0036 and F0037 were identified as Alteromonas fortis with similarity of $99.56 \%$ and $99.40 \%$, respectively. Threshold of $98.65 \%$ similarity for bacterial delineation using 16S rRNA gene has been proposed previously by Kim et al. (2014) to differentiate two bacterial species. Alteromonas is a genus of Proteobacteria found in sea water, either in the open ocean or in the coast. Its cells are curved rods with a single polar flagellum (Barbeyron et al. 2019). Genus Alteromonas have been well-documented previously as probiotic in aquaculture (Kesarcodi et al. 2010). The genus was reported to increase the survival of Pacific oyster, Crassostrea gigas, when administered in water (Irianto and Austin 2002), inhibit pathogenic bacteria Vobrio harveyii and promote the growth and survival of shrimp larvae (Haryanti et al. 2017). A. fortis is a non-flagellated bacterium specialized in the degradation of iotacarrageenan (Barbeyron et al. 2019). There were no reports so far on the presence of $A$. fortis in culture of rotifer and fish larvae.

Altogether, we show here that culture medium of rotifer fed FWD containing 5 different bacterial species i.e. $B$. cereus sp. complex (F0031), V. rotiferanus (F0032), B. jeotgali (F0033), S. warneri (F0035), and A. fortis (F0036; F0037) in the genus of Bacillus, Vibrio, Staphylococcus and Alteromonas. The bacterial species may involve in decomposing the FWD and further become food source for rotifer.

\section{ACKNOWLEDGEMENTS}

This work is funded by the Indonesian Ministry of Research and Technology (Kemenristek) /National Agency for Research and Innovation (BRIN) Indonesia to SW.

\section{REFERENCES}

Acién FG, Molina E, Fernández-Sevilla JM, Barbosa M, Gouveia L, Sepulveda C, Bazaes J, Arbib Z. 2017. Economics of microalgae production. In Microalgae-based biofuels and bioproducts. Woodhead Publishing, United Kingdom.

Akihary CV, Kolondam BJ. 2020. Pemanfaatan gen 16s rrna sebagai perangkat identifikasi bakteri untuk penelitian-penelitian di Indonesia. Pharmacon 9 (1): 16-22.

Barbeyron T, Zonta E, Le Panse S, Duchaud E, Michel G. 2019. Alteromonas fortis sp. nov., a non-flagellated bacterium specialized in the degradation of iota-carrageenan, and emended description of the genus Alteromonas. Int J Syst Evol Microbiol 69 (8): 2514-2521.

Bottone EJ. 2010. Bacillus cereus, a volatile human pathogen. Clin Microbiol Rev 23 (2): 382-398.

Chandran MN, Iyapparaj P, Moovendhan S, Ramasubburayan R, Prakash S, Immanuel G. 2014. Influence of probiotic bacterium Bacillus cereus isolated from the gut of wild shrimp Penaeus monodon in turn as a potent growth promoter and immune enhancer in P. monodon. Fish Shellfish Immunol 36: 38-45. 
Chowdhury PR, Boucher Y, Hassan KA, Paulsen IT, Stokes HW, Labbate M. 2011. Genome sequence of Vibrio rotiferianus strain DAT722. J Bacteriol 193 (13): 3381-3382.

Clément P. 1987. Movements in rotifers: Correlations of ultrastructure and behavior. Hydrobiol 147: 339-359.

Divya M, Aanand S, Srinivasan A, Ahilan. 2015. Bioremediation-An ecofriendly tool for effluent treatment: A review. Int J Appl Res 1: 530537.

Fiałkowska E, Klimek B, Marchlewicz A, Kocerba-Soroka W, Starzycka J, Walczyńska A, Pajdak-Stós A. 2019. Diversity and function of the microbial community under strong selective pressure of rotifers. J Basic Microbiol 59 (8): 775-783.

Fuks G, Elgart M, Amir A, Zeisel A, Turnbaugh PJ, Soen Y, Shental N. 2018. Combining 16S rRNA gene variable regions enables highresolution microbial community profiling. Microbiome 6 (1): 1-13.

Haché R, Plante S. 2011. The relationship between enrichment, fatty acid profiles and bacterial load in cultured rotifers (Brachionus plicatilis L-strain) and Artemia (Artemia salina strain Franciscana). Aquac 311 (1-4): 201-208

Hagiwara A, Kim HJ, Marcial H. 2017. Mass culture and preservation of Brachionus plicatilis sp. complex. In: Hagiwara A, Yoshonaga T (eds). Rotifers Aquaculture, Ecology, Gerontology, and Ecotoxicology. Springer, Singapore.

Hagiwara A, Wullur S, Marcial HS, Hirai N, Sakakura Y. 2014 Euryhaline rotifer Proales similis as initial live food for rearing fish with small mouth. Aquaculture 432: 470-474.

Hannan MA, Rahman MM, Mondal MN, Deb SC, Chowdhury G, Islam MT. 2019. Molecular Identification of Vibrio alginolyticus Causing Vibriosis in Shrimp and Its Herbal Remedy. Polish J Microbiol 68 (4): $429-438$

Haryanti H, Sugama K, Tsumura S, Nishijima R. 2017. Enhance production of black tiger shrimp Penaeus monodon postlarvae by probiotic bacterium Alteromonas sp. Indones Fish Res J 7 (1): 1-6.

He RP, Feng J, Tian JL, Dong SL, Wen B. 2017. Effects of dietary supplementation of probiotics on the growth, activities of digestive and non-specific immune enzymes 8 in hybrid grouper (Epinephelus lanceolatus and Epinephelus fuscoguttatus). Aquac Res 48: 5782 5790 .

Irianto A, Austin B. 2002. Probiotics in aquaculture. J Fish Dis 25 (11): 633-642.

Istiqomah I, Isnansetyo A. 2020. Review vibriosis management in indonesian marine fish farming. E3S Web of Conf. DOI: 10.1051/e3sconf/202014701001.

Ke HM, Prachumwat A, Yu CP, Yang YT, Promsri S, Liu KF, Lo CF, Lu MYJ, Lai MC, Tsai IJ, Li WH. 2017. Comparative genomics of Vibrio campbellii strains and core species of the Vibrio Harveyi clade. Sci Rep 7 (1): 1-11.

Kesarcodi-Watson A, Kaspar H, Lategan MJ, Gibson L. 2010 Alteromonas macleodii 0444 and Neptunomonas sp. 0536, two nove probiotics for hatchery-reared Greenshell ${ }^{\mathrm{TM}}$ mussel larvae, Perna canaliculus. Aquaculture 309 (1-4): 49-55

Kim M, Oh HS, Park SC, Chun J. 2014. Towards a taxonomic coherence between average nucleotide identity and $16 \mathrm{~S}$ rRNA gene sequence similarity for species demarcation of prokaryotes. Int J Syst Evol Microbiol 64: 346-351.

Kotani T. 2017. The current status of the morphological classification of rotifer strain used in aquaculture. In: Hagiwara A, Yoshonaga T (eds) Rotifers Aquaculture, Ecology, Gerontology, and Ecotoxicology. Springer, Singapore.

Lee MC, Park JC, Yoon DS, Choi H, Shin KH, Kim HJ, Hagiwara A, Lee JS. 2019. Lipid metabolism modulation by five different food types in the monogonont marine rotifer Brachionus koreanus. Aquaculture 503: 596-601.

Liu Y, Lai Q, Du J, Shao Z. 2017. Genetic diversity and population structure of the Bacillus cereus group bacteria from diverse marine environments. Sci Rep 7 (1): 1-11.

Loka J, Sonali SM, Saha P, Devaraj K, Philipose KK. 2016. Use of commercial probiotics for the improvement of water quality and rotifer density in outdoor mass culture tanks. Indian J Fish 63 (4) 145-149.

Loo PL, Chong VC, Vikineswary S, Ibrahim S. 2016. Waste-grown phototrophic bacterium supports culture of the rotifer, Brachionus rotundiformis. Aquac Res 47 (10): 3029-3041.

Md SA, Nour AM, Srour TM, Assem SS, Ibrahim HA, El-Sayed HS 2015. Greenwater, Marine Bacillus subtilis HS1 probiotic and synbiotic enriched artemia and rotifers improved European seabass
Dicentrarchus labrax larvae early weaning length growth, survival, water and bacteriology quality. Am J Life Sci 3 (6-1): 45-52.

Miller RA, Beno SM, Kent DJ, Carroll LM, Martin NH, Boor KJ, Kovac J. 2016. Bacillus wiedmannii sp. nov., a psychrotolerant and cytotoxic Bacillus cereus group species isolated from dairy foods and dairy environments. Intl J Syst Evol Microbiol 66 (11): 4744-4753.

Murillo I, Villamil L. 2011. Bacillus cereus and Bacillus subtilis used as probiotics in rotifer (Brachionus plicatilis) cultures. J Aquac Res Dev. DOI: 10.4172/2155-9546.S1-007.

Musharrafieh R, Tacchi L, Trujeque J, LaPatra S, Salinas I. 2014. Staphylococcus warneri, a resident skin commensal of rainbow trout (Oncorhynchus mykiss) with pathobiont characteristics. Vet Microbiol 169 (1-2): 80-88.

Napitupulu HG, Rumengan IF, Wullur S, Ginting EL, Rimper JR, Toloh BH. 2019. Bacillus sp. as a decomposition agent in the maintenance of Brachionus rotundiformis which uses raw fish as a source of nutrition. Jurnal Ilmiah Platax 7 (1): 158-169. [Indonesian]

Nevejan N, De Schryver P, Wille M, Dierckens K, Baruah K, Van Stappen G. 2018. Bacteria as food in aquaculture: Do they make a difference? Rev Aquac 10 (1): 180-212.

Ogello EO, Wullur S, Hagiwara A. 2019. Blending fishwastes and chicken manure extract as low-cost and stable diet for mass culture of freshwater zooplankton, optimized for aquaculture. IOP Conf Ser Mater Sci Eng 567: 012022. DOI: 10.1088/1757-899X/567/1/012022

Ogello EO, Wullur S, Sakakura Y, Hagiwara A. 2018. Composting fishwastes as low-cost and stable diet for culturing Brachionus rotundiformis Tschugunoff (Rotifera): Influence on water quality and microbiota. Aquaculture 486: 232-239.

Ogello EO, Wullur S, Yoshitaka S, Hagiwara A. 2020. Dietary value of waste-fed rotifer Brachionus rotundiformis on the larval rearing of japanese whiting Sillago japonica. E3S Web of Conferences. DOI: $10.1051 / \mathrm{e} 3$ sconf/202014701005.

Onianwah IF, Stanley HO, Oyakhire MO. 2018. Microorganisms in sustainable aquaculture development. Global Adv Res J Microbiol 7 (8): 127-131,

Rumengan IFM, Sulung M, Lantiunga Z, Kekenusa J. 2016. Morfometri Rotifer Brachionus rotundiformis strain SS asal tambak Minanga dan tambak Watuliney Sulawesi Utara yang dikultur pada salinitas yang berbeda. Jurnal Riset Akuakultur 2 (2): 221-229. [Indonesian]

Sahandi J, Sorgeloos P, Xiao H, Wang X, Qi Z, Zheng Y, Tang X. 2019. The use of selected bacteria and yeasts to control Vibrio spp. in live food. Antibiotics 8 (3): 1-16.

Sousa AM, Pereira MO, Lourenç A. 2015. MorphoCol: An ontologybased knowledgebase for the characterisation of clinically significant bacterial colony morphologies. J Biomedic Inform 55: 55-63.

Sultani M, Ghosh K, Hoseinifar SH, Kumar V, Lymbery AJ, Roy S, Ring $\varnothing$ E. 2019. Genus Bacillus, promising probiotics in aquaculture: Aquatic animal origin, bio-active components, bioremediation and efficacy in fish and shellfish. Rev Fish Sci Aquac 27 (3): 331-379.

Vargas-Albores F, Porchas-Cornejo MA, Martinez-Porshas M, Villalpando E, Gollas-Galvan T, Martinez-Cordova LR. 2017. Bacterial biota of shrimp intestine is significantly modified by the use of a probiotic mixture: A high throughput sequencing approach. Helgoland Mar Res 71 (5): 1-10.

Wantania LL, Wullur S, Ginting EL, Mantiri DM, Undap SL, Sumilat DA, Gerung GS. 2019. Isolation and amplification of 16S rRNA gen of associated microbial isolates in red algae Kappaphycus alvarezii from Belang, Southeast Minahasa Regency, North Sulawesi. Jurnal Ilmiah Platax 7 (1): 220-226. [Indonesian]

Wati M, Imanto PT. 2016. Kultur rotifer dengan beberapa jenis pakan dan kombinasinya. Jurnal Riset Akuakultur 4 (3): 349-356. [Indonesian]

Wondal B, Ginting EL, Warouw V, Wullur S, Tilaar SO, Tilaar FF. 2019. Isolasi bakteri laut dari perairan Malalayang, Sulawesi Utara. Jurnal Pesisir dan Laut Tropis 7 (3): 183-189. [Indonesian]

Wullur S, Ginting EL, Waraow V, Rumengan IFM, Ogello EO, Hagiwara A. 2019. Growth response of rotifers on a bacterial-based diet made from fishwastes. IOP Conf Ser Mater Sci Eng 567: 012030. DOI: 10.1088/1757-899X/567/1/012030.

Wullur S, Kumagai S, Sakakura Y, Hagiwara A. 2018. Assessment of different minute zooplankton in the larval rearing of rusty angelfish Centropyge ferrugata. AACL Bioflux 11 (5): 1495-1501.

Wullur S, Sakakura Y, Hagiwara A. 2011. Application of the minute monogonont rotifer Proales similis de Beauchamp in larval rearing of seven-band grouper Epinephelus septemfasciatus. Aquaculture 315 (3-4): 355-360 
Wullur S, Yoshimatsu T, Tanaka H, Ohtani M, Sakakura Y, Kim HJ, Hagiwara A. 2013. Ingestion by Japanese eel Anguilla japonica larvae on various minute zooplanktons. Aquac Sci 61 (4): 341-347.

Wullur S. 2017. Rotifer dalam Perspektif Marikultur. LPPM Press, Menado. [Indonesian]

Xue M, Wen C, Liang H, Ding M, Wu Y, Li X. 2016. In vivo evaluation of the effects of commercial Bacillus probiotics on survival and development of Litopenaeus vannamei larvae during the early hatchery period. Aquac Res 47 (5): 1661-1669.
Yao Z, Meng Y, Le HG, Kim JA, Kim JH. 2019. Isolation of Bacillus subtilis SJ4 from Saeu (Shrimp) jeotgal, a Korean fermented seafood, and its fibrinolytic activity. J Korean Soc Microbiol Biotechnol 47 (4): 522-529.

Yoon SH, Ha SM, Kwon S, Lim J, Kim Y, Seo H, Chun J. 2017. Introducing EzBioCloud: a taxonomically united database of $16 \mathrm{~S}$ rRNA gene sequences and whole-genome assemblies. Intl J Syst Evol Microbiol 67 (5): 1613. 